\title{
Charitable Behavior of Muslim in Indonesia during the COVID-19 Pandemic: A Tobit Model Analysis
}

\author{
Agni Alam Awirya a, Indah Piliyanti b* , Dian Novita c \\ ${ }^{a}$ Bank Indonesia, Indonesia \\ ${ }^{b}$ Faculty of Islamic Economics and Business, UIN Raden Mas Said Surakarta, Indonesia \\ ${ }^{c}$ Faculty of Economics and Business, Universitas Airlangga, Indonesia \\ * Corresponding email: indah.piliyanti@iain-surakarta.ac.id \\ http://dx.doi.org/10.22515/shirkah.v6i3.436
}

\begin{tabular}{|c|c|}
\hline ARTICLE INFO & ABSTRACT \\
\hline $\begin{array}{l}\text { Keywords: } \\
\text { Charitable Behavior; COVID- } \\
19 \text { Pandemic; Islamic } \\
\text { Philanthropy; Tobit Regression }\end{array}$ & $\begin{array}{l}\text { The COVID-19 pandemic has caused a decline in social } \\
\text { welfare. In such a situation, community philanthropy, } \\
\text { including from the Muslim community, becomes critical. } \\
\text { This study aims to explore the charitable behavior of }\end{array}$ \\
\hline $\begin{array}{l}\text { Article history: } \\
\text { Received: } 13 \text { August } 2021 \\
\text { Revised: } 05 \text { December } 2021 \\
\text { Accepted: } 28 \text { December } 2021 \\
\text { Available online: } 31 \text { December } \\
2021\end{array}$ & $\begin{array}{l}\text { Muslims in Indonesia during the COVID- } 19 \text { pandemic. The } \\
\text { Tobit regression was used to analyze data from online } \\
\text { surveys to determine the pattern changes of donations } \\
\text { during the pandemic as well as the factors affecting the } \\
\text { amount of donation. This study uncovered that Zakat } \\
\text { Management Organizations (BAZNAS and LAZ) were some } \\
\text { of the main choices for distributing zakat and alms (sedekah) }\end{array}$ \\
\hline $\begin{array}{l}\text { To cite in APA style: } \\
\text { Awirya, A. A., Piliyanti, I., \& } \\
\text { Novita, D. (2021). Charitable } \\
\text { Behavior of Muslim in } \\
\text { Indonesia during the COVID- } \\
19 \text { Pandemic: A Tobit Model } \\
\text { Analysis. Shirkah: Journal of } \\
\text { Economics and Business, 6(3), } \\
\text { 361-379. }\end{array}$ & $\begin{array}{l}\text { during the pandemic. It was found that the factors with a } \\
\text { positive and significant effect on the probability of } \\
\text { increasing the percentage of donations were education, } \\
\text { length of stay, and expenses. The results of this study } \\
\text { contribute to the policy of developing the Zakat } \\
\text { Management Organization as institutions trusted by the } \\
\text { community in distributing zakat funds. This study supports } \\
\text { the fundraising of the zakat organizations in terms of } \\
\text { offering valuable insights and clear description about the } \\
\text { Indonesian people's charitable behavior. More importantly, } \\
\text { this study suggests that improving the quality of education } \\
\text { is crucial to increase community awareness in performing } \\
\text { Islamic philanthropy such as giving zakat, sedekah, and waqf. }\end{array}$ \\
\hline $\begin{array}{l}\text { This work is } \\
\text { International }\end{array}$ & under a Creative Commons Attribution-NonCommercial 4.0 \\
\hline
\end{tabular}




\section{Introduction}

The COVID-19 pandemic has hit 227 countries including Indonesia. It has impacted social welfare. Restrictions towards community activities have caused the closure of many businesses (Ozili, 2021). This resulted in workforce reduction causing unemployment (Galea \& Abdalla, 2020). The Ministry of Manpower of the Republic of Indonesia reported that more than 1.7 million workers in Indonesia were laid off and fired. Some of them did not receive their full salary, some others did not receive a salary at all. This led to an increase in poverty during the pandemic in mid-2020 (Martin et al. (2020). The impact of the decline in welfare due to the COVID-19 pandemic is expected to be higher, especially in developing countries. The severity of the impact depends on how long the COVID-19 pandemic will last (Sumner et al., 2020).

The COVID-19 outbreak is more than just intensive care and health crisis phenomenon, but also a humanitarian crisis (Nacoti et al., 2020). In 2020, more than 168 million people infected in various countries around the globe were estimated to need humanitarian assistance. The population who are vulnerable to COVID-19 are those affected by the humanitarian crisis due to the absence of the roles of individuals and groups in helping each other (Poole et al., 2020). Hence, the role of the community to help each other is needed in overcoming the impact of the COVID-19 pandemic on the health and welfare sector to survive in very difficult conditions.

The community participation that can be optimized, especially in Indonesia, is zakat, alms (sedekah), and waqf from the Muslim community. History records that Muslim philanthropy funds have contributed to various crises that have occurred in Indonesia even before Independence (Fauzia, 2016). During this current pandemic, with the largest Muslim population, Islamic philanthropy plays an important role in helping people affected by the COVID-19 pandemic. The distribution of Muslim funds in Indonesia is carried out in various ways, be it independently or through social institutions/Zakat management organizations (henceforth OPZ). OPZ consists of the National Zakat Agency or BAZNAS (Zakat institution established by the government) and the Zakat Institution or LAZ (Zakat institution established by the community) (Piliyanti, 2020). OPZ as one of the social institutions in an Islamic society can optimize its function as an institution collecting and distributing community funds (in the forms of zakat and sedekah) to people in need. Funds collected from muzakki (Muslim who obliges to pay zakat) can be directly distributed to mustahik (a person who receives zakat) during this pandemic. As an institution that has experience in distributing funds (Fauzia, 2016), its role is very important in this time of pandemic. The Majelis Ulama Indonesia (Indonesian Ulema Council) fatwa also strengthens that zakat funds can be allocated to help victims affected by COVID-19 (Ismail et al., 2020). 
Referring to the description previously elaborated, under the current outbreak, zakat can be used as a source of funding in responding to COVID-19 pandemic. However, the use of zakat funds in this situation cannot be carried out freely, it must be based on clear provisions concerning the function of zakat (Saputra, 2020). With its important contribution during a pandemic, if the management, utilization, and distribution of zakat are used properly and optimally, it will help the government and society in dealing with the shocks of the COVID-19 pandemic (Amalia, 2012). In addition, Islamic philanthropic institutions are said to be able to contribute to increasing economic growth amid the COVID-19 pandemic if they can manage short and long-term zakat, sedekah, and waqf (Masrul \& Huda, 2021).

Several studies have been conducted investigating the role of Muslim zakat and sedekah in their contribution to handling the COVID-19 pandemic. The role of Muslims in various models of philanthropy in Islamic economics and finance can overcome economic shocks and contribute to recovering these economic shocks (Iskandar et al., 2020). In a study conducted by Asmalia et al. (2018), the implementation of zakat has a big influence in handling COVID-19 effect. In regards to the welfare of the Muslim community, good distribution of zakat funds is the main determinant in overcoming and recovering the shocks of the COVID-19 pandemic.

The role of Zakat in dealing with the COVID-19 pandemic has also been discussed in a study conducted by Heider Syed et al. (2020). The study revealed that Islamic finance has great potential to overcome pandemic challenges. The combination of zakat and Qardh-Al-Hasan is well contributing to preventing the effects of COVID-19. The contribution of zakat in dealing with the impact of pandemic includes the provision of scholarships, basic necessities, and assistance to orphanages (Mursal et al., 2021). The distribution of Zakat funds in the context of tackling COVID-19 can also be done in the form of food for consumption (Wahyu \& Anwar, 2020).

The majority of previous studies seek to examine the contribution of zakat funds to the handling of the COVID-19 pandemic without taking into account factors affecting the percentage of zakat funds given by Muslims during the pandemic. Thus, this becomes the focus of this study. This study fills the gap and overcomes the limitations by analyzing the pattern of disbursement of zakat funds and the factors affecting the number of zakat funds given by Muslims. To achieve the research objectives, this study involved independent variables of gender, age, education, family size, length of stay, employment, and expenses. The variables were selected by reviewing empirical studies.

This study investigated the role of Muslim's zakat and sedekah by analyzing the pattern of disbursement of zakat and sedekah funds given by Muslims during the COVID-19 pandemic through a survey. This study was expanded to analyze the factors 
that affect the number of donations given by respondents related to zakat and sedekah to help the community during the COVID-19 pandemic. The results of this study are expected to provide an overview of the disbursement of Muslim funds in Indonesia during the COVID-19 pandemic. For policymakers, this research can be inputs for the optimization of OPZ (BAZNAS and LAZ) related to its function of collecting, distributing, and utilizing zakat and sedekah funds during a pandemic.

\section{The Role of Zakat during the COVID-19 Pandemic}

Zakat is one of the important foundations in Islamic economics that is often associated with efforts to achieve economic prosperity for peace, security, and harmony (AlFazizin et al., 2017). Zakat has important implications in relation to achieving allocation efficiency, income distribution, and economic growth (Saputro \& Sidiq, 2020). Philosophically, zakat is defined as supporting funds used to ensure the fulfillment of community needs and welfare (Asmalia et al., 2018; Saladin et al., 2011). In this current outbreak, zakat is used as an option to support funding for the lower middle class.

Zakat is also used to reduce the impact of the COVID-19 pandemic that leads to the consideration of Islamic social finance instruments (Umar et al., 2021). It was done to help community finance (Micro, Small, and Medium Enterprises) as well as to finance other productive purposes (Hassan \& Noor, 2015). According to a study by Sulaeman et al., (2021), there has been an increase in the collection and distribution of zakat funds which can effectively reduce poverty levels as in line with the program proposed by the Indonesian government related to poverty reduction to recover the economy after COVID-19. The study also supports that zakat is not only beneficial for the social sector but also has a positive impact on the community's economic development. A similar study was also conducted by Munandar et al. (2020) that the distribution of zakat funds and economic growth significantly affects the poverty level in Indonesia.

\section{Individual Factors in Prosocial Behavior}

Prosocial behavior has a certain level of sacrifice aimed at helping others without expecting benefits from individuals who carry out these activities (Andreoni et al., 2021). Factors that cause prosocial differences can be categorized into several parts, including age and gender. Someone with older age will have a higher prosocial value (Jin et al., 2021). Compared to younger people, older people are more willing to help others and exert the same power on themselves and others (Lockwood et al., 2021). This is based on the premise that older people become more prosocially motivated. However, other studies suggest that older age is associated with increased apathy, decreased motivation, and goal-directed behavior (Van Reekum et al., 2005). Therefore, 
compared to younger people, older people may be less willing to engage in prosocial actions (Kamas \& Preston, 2021).

Meanwhile, when it comes to gender, women are said to be more concerned with prosocial values than men (Van Reekum et al., 2005). In a study carried out by Abdullahi and Kumar (2016), men and women have the same position in terms of dimensions of prosocial behavior. However, women are on the higher level which indicates that they have a better understanding of caring in society. Kamas and Preston (2021) state that men tend not to do prosocial activities such as donating their funds, but when they do, they donate in larger amounts than women.

\section{Socio-Economics and Cultural Prosocial Moves}

Several other social, economic, and cultural factors are considered to affect a person's prosocial behavior. High level of education can be used as a measure of a person's sensitivity to the surrounding. It is said that an individual's tendency to behave prosocially or generously depends on natural and upbringing factors, one of which is education (Rietveld et al., 2013). Someone with a high level of education is considered to be more understanding, thus will be able to understand the surrounding. However, other studies have shown that people who act prosocially or generously have expectations that their generosity will be reciprocated and will help their reputation in certain groups (Kamas \& Preston, 2021). Prosocial behavior is also influenced by cultural norms. Hence, it will be easier to form in individuals involving certain groups. Empathy, compassion, and other emotions will be higher in the groups of individuals that have long been formed.

Meanwhile, if it is based on economic factors related to how much a person's expenses and income are associated with social status, a research conducted by James and Sharpe (2007) indicates that the poorest and richest people give the most of their income to help each other. People who are in the highest income group are the most likely to be prosocial by helping others (Li, 2015). This is also closely related to one's employment. Employment with higher strata will be associated with higher income and expenses as well. A study conducted by Smith (2016) asserts that someone who possesses a more prestigious occupation will be more likely to be prosocial. Another variable, the number of dependents, can be associated with a person's expenses. The higher the number of dependents, the smaller income per individual. Keister et al. (2000) say that family size tends to decrease wealth.

\section{Method}

\section{Research Design}

The present study aims to depict the charitable behavior of Muslim in Indonesia in the 
time of COVID-19 pandemic. To reach the objective, a survey research was conducted by employing an online questionnaire to a group of Muslim people in Indonesia whose age is above 20. Table 1 shows the detailed survey items.

Table 1. Variable Description

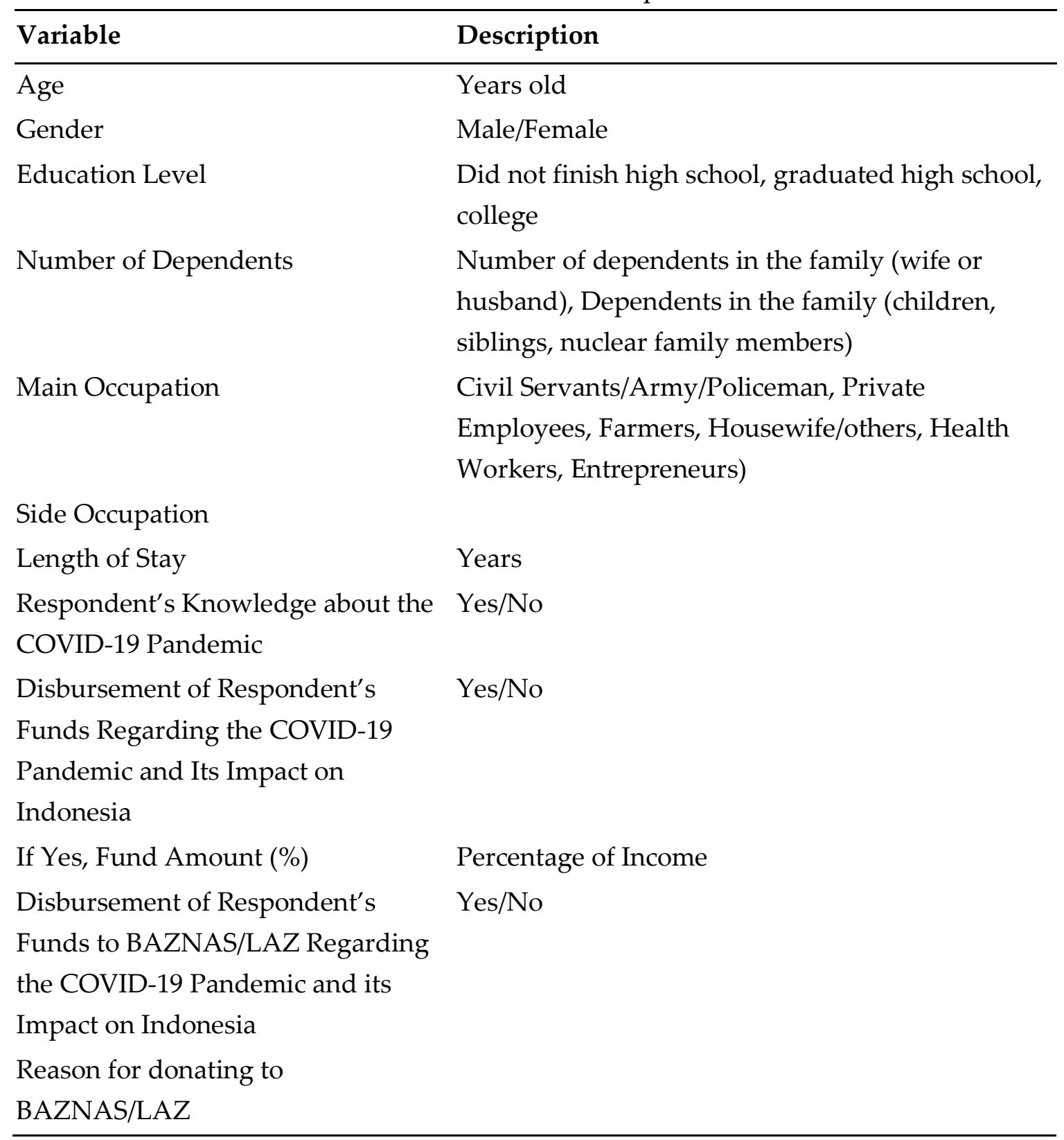

\section{Participants and Data Collection}

This study used primary data. The data collection employed an online survey since the pandemic hampered the direct survey method. An online survey with a nonprobabilistic sampling method was utilized in this study. The online survey targeted Muslims who have capacity to donate or those we estimated to be included as muzakki (people who pay zakat). To minimize the sampling bias, we targeted heterogeneous 
samples. The target respondents were religious communities such as recitation groups and non-religious groups such as alumni of public schools. Most of the respondents were domiciled in Central Java province Indonesia. The composition of respondents from religious and non-religious groups was sought to be equally distributed. The heterogeneity of the survey results is maintained to provide more accurate results.

There were 260 respondents who answered the online survey. After cleaning the data, 225 respondents were obtained. They consisted of $62 \%$ from religious groups and the remaining $38 \%$ were from non-religious groups. The digital questionnaire distributed consisted of three parts. The first part is the demographics of the respondents. The second part deals with information related to the respondent's socioeconomic such as employment and household expenses. The third part relates to information regarding the characteristics of zakat and sedekah such as the nominal amount of zakat and sedekah, the choice of institutions in the disbursement, and perceptions regarding the priority of zakat and sedekah targets. We did not carry out further analysis of the part of the questionnaire capturing information regarding COVID-19 since the quality of the data in that part was too homogeneous.

\section{Data Analysis}

This study used descriptive statistics and inferential statistics. Descriptive statistics deals with data presented in the form of tables, graphs, diagrams as well as other quantities such as mean, mode, median (Walpole, 1995). Several aspects analyzed in this part were whether the respondents donate for COVID-19 and the reasons behind it. This part also discussed whether the respondent disburses funds to BAZNAS/LAZ as well as the reasons.

Inferential statistical carried out in this study used the Tobit regression. The Tobit model (Tobin, 1958) belongs to the class of econometric techniques that are traditionally considered censored regression models (Woldridge, 2002). The standard Tobit model or Tobit type 1 is defined as follows:

$$
\begin{gathered}
y_{i}{ }^{*}=x_{i} \beta+u_{i} \\
y_{i}=y_{i}{ }^{*} \text { if } y_{i}{ }^{*}>0 \\
y_{i}=0 \text { if } y_{i}{ }^{*}>0 \\
i=1,2,3, \ldots \ldots, n
\end{gathered}
$$

Where $u_{i}$ is assumed to be identical and independent data obtained from $N(0, \sigma 2)$. Another assumption is that $\mathrm{y}_{i}$ and $\mathrm{x}_{\mathrm{i}}$ are observed for $\mathrm{i}=1,2,3 \ldots ., \mathrm{n}$ but $\mathrm{yi}_{\mathrm{i}}^{*}$ is not observed if $y_{i}{ }^{*} \leq 0$. $\underline{X}$ is defined as a $(n \times K)$ matrix with line is $x_{i}{ }^{\prime}$, the researcher assumes that $x_{i}$ is finite and uniform. $\lim _{n \rightarrow \infty} n^{-1} \underline{X}^{\prime} \underline{X}$ is positive definite. The form of parameters $\beta$ and $\sigma 2$ is assumed to be compact. In the Tobit model, it is necessary to separate the vector- 
matrix of positive observations in the vector and the matrix of all observations.

The equation $y_{i}{ }^{*}>0$ and $y_{i}{ }^{*} \leq 0$ can be replaced by $y_{i}{ }^{*}>y 0$ and $y_{i}{ }^{*} \leq$ $y 0$ without replacing the model essentially in the known or unknown y0, because y0 can be taken from the constant term in the regression. If it is found that the value of $\mathrm{y}_{\mathrm{i}}$ changes with a known $i$ for each $i$, the model will change very little because the final result of the model will essentially be the same as the model $y_{i}{ }^{*}=x_{i} \beta+u_{i}$ and $y_{i}=y_{i}{ }^{*}$ if $y_{i}{ }^{*}>0$ where one of the elements $\beta$ and the constant term are known. A model in which $\mathrm{y}_{\mathrm{i}}$ changes with $\mathrm{i}$ and is unknown cannot be estimated in general.

The likelihood function for the standard Tobit model is:

$$
L=\prod_{0}\left[1-\Phi\left(x_{i}^{\prime} \beta / \sigma\right)\right] \prod_{1} \sigma^{-1} \phi\left[\left(y_{i}-x_{i}^{\prime} \beta\right) / \sigma\right]
$$

Where $\Phi$ and $\varnothing$ are distributed and the function is solid, orderly, from variables with normal the standard. The Tobit model is included in the censored regression model. On the other hand, when we do not observe yi or xi when $\llbracket \llbracket y \rrbracket \_i \rrbracket{ }^{\wedge *} \leq 0$, then the model is included in the truncated regression model. The likelihood function of the truncated regression model is:

$$
L=\prod_{0} \Phi\left(x_{i}^{\prime} \beta / \sigma\right)^{-1} \sigma^{-1} \phi\left[\left(y_{i}-x_{i}^{\prime} \beta\right) / \sigma\right]
$$

Truncated regression model or truncated regression is used if the dependent variable is limited at a certain point. This regression was introduced by Tobin in 1958. It estimates the household expenses that cannot be negative. In this study, the researcher used the lower limit or lower level of the model as 0 and the upper limit or upper level of the model is 1 . Thus, the value of each $Y$ is in the range $0-1$.

After a literature study regarding several variables considered rational to be used as determining factors in prosocial action, model specifications were adopted in several studies. Some of the variables adopted are gender (Kamas \& Preston, 2021; Rietveld et al., 2013), Age (Lockwood et al., 2021), Education (Umar et al., 2021; Smith, 2016; Rietveld et al., 2013, Employment (Smith, 2016), length of stay (Allen, 2018), and expenses (Clotfelter \& Steuerle, 1981; James \& Sharpe, 2007). This study includes the variable of family size that explains the number of dependents. The researchers tried to accommodate previous studies related to these eight variables in different formations and presentations.

Thus, the model specifications related to the percentage of funds for COVID-19 can be written as follows:

$\%$ Disbursement Fund

$=f($ Gender, Age, Family size, Education, Main Job, Side Job, Length of stay, Expenditure) 


\section{Results}

\section{Descriptive Statistics}

At the beginning of the descriptive statistics, the distribution of respondents based on gender, age, education, length of stay, and main occupation is described in the following figures. Figure 1 depicts the distribution of respondents in this study with $61 \%$ female respondents and 39\% male respondents. Meanwhile, the majority of main occupations of respondents was civil servants/Army/Policeman by $43 \%$, private employees by $31 \%$, housewives or others by $14 \%$, entrepreneurs by $8 \%$, health worker by $3 \%$, and farmer by $1 \%$ (see Figure 2 ).

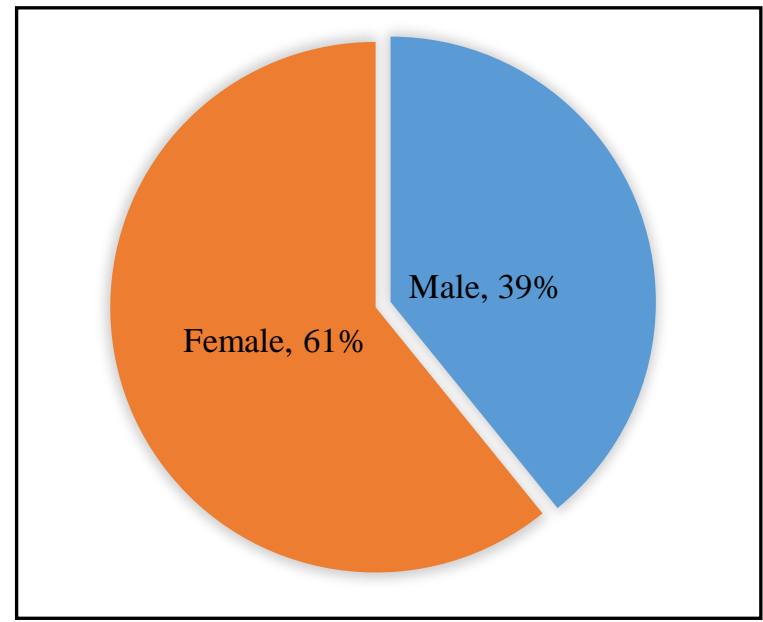

Figure 1. Respondents' Gender

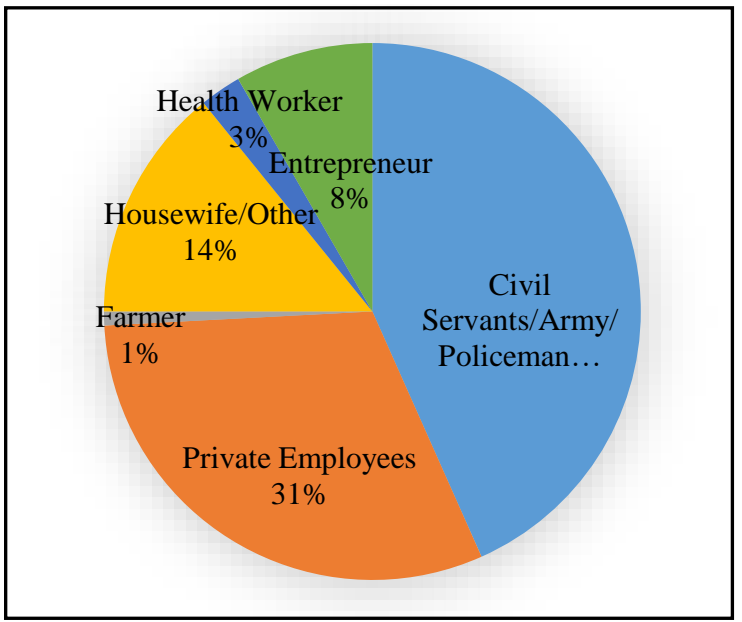

Figure 2. Respondents' Occupation

Referring to the age distribution of the respondents, the average age of respondent filling out the survey was 34 years old (see Figure 3), most of which were dominated by respondents with a college education level. Meanwhile, Figure 4 delineates the average length of stay of respondents in each domicile in the range of 412 years. The length of stay can be used as a proxy in the respondent's concern for disbursing funds related to the COVID-19 to their area.

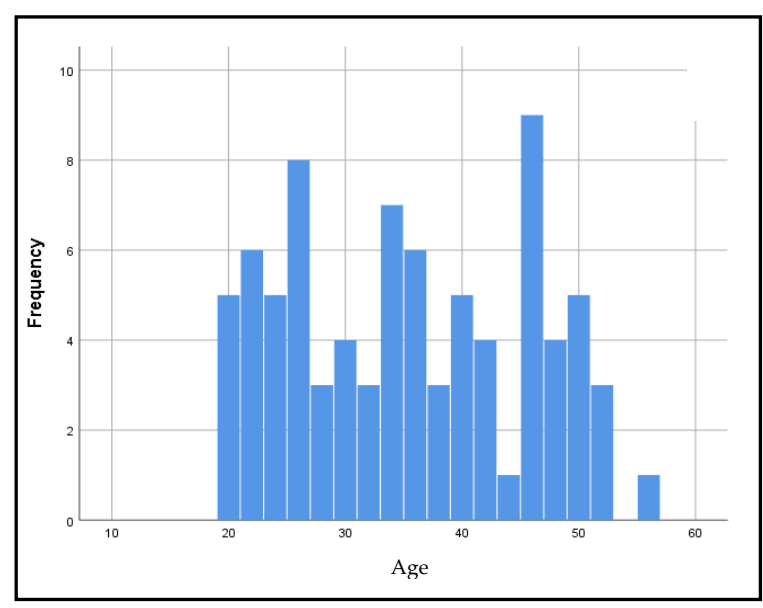

Figure 3. Respondents' Age

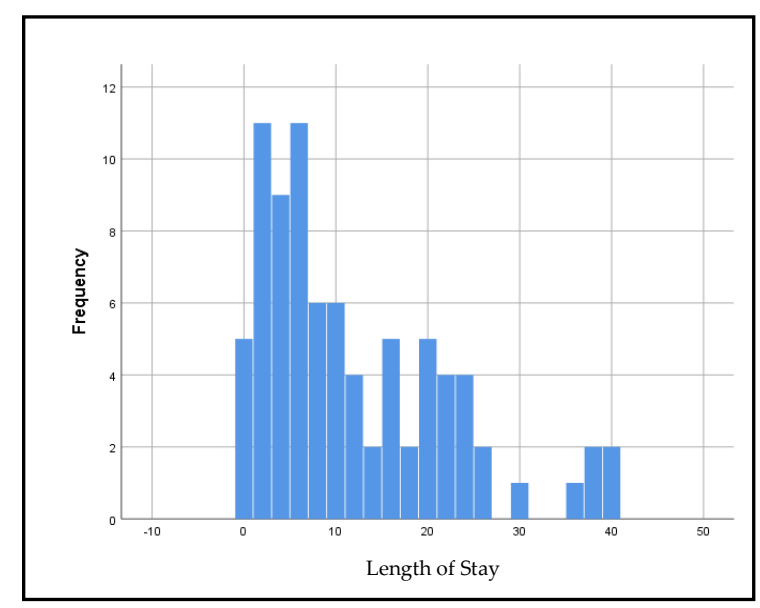

Figure 4. Respondents' Length of Stay 
Based on the survey results, most respondents donated funds during the pandemic. $50 \%$ of those allocated funds regularly with the average donation given of $8 \%$ of their monthly income. The other $50 \%$ answered no (see Figure 5 ). The reason underlying respondents did not disburse their funds was dominated by financial difficulties due to the COVID-19 pandemic (87\%), overcoming the pandemic is the government's task $(10 \%)$, and paying taxes already representative in the contribution to the response to the COVID-19 pandemic (2\%). 56\% of the respondents donated their funds through Zakat institution and the remaining $44 \%$ donated directly to mustahik. It is assumed that they followed the pattern of disbursing funds before the pandemic (see Figure 6).

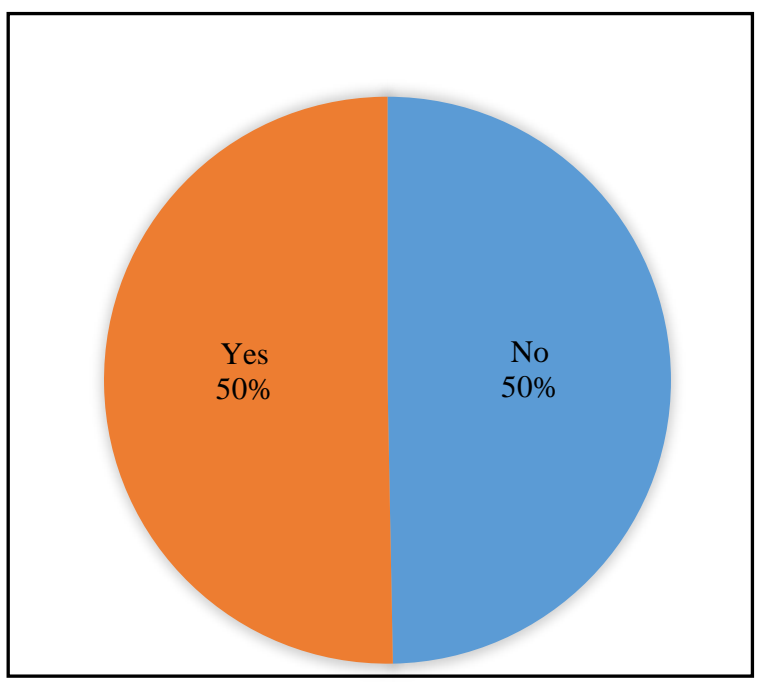

Figure 5. Donation for COVID-19

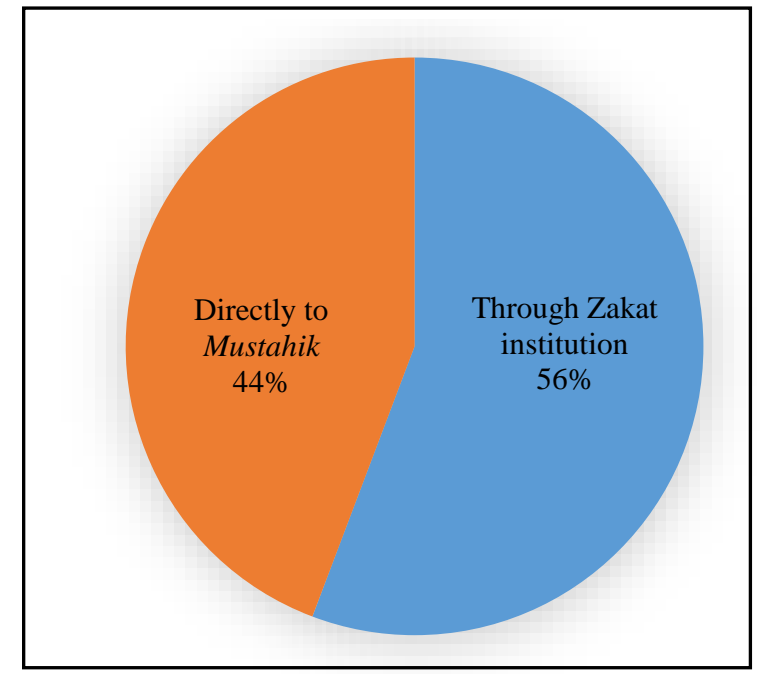

Figure 6. Distribution of Funds Pandemic

Based on the respondents' reasons, the fund disbursement before and in the time of the pandemic was dominated by zakat management organizations or other social institutions (see Figure 7 and Figure 8). In addition, Figure 9 demonstrates that most of the respondents admitted that the distribution of funds through BAZNAS or LAZ is more secure than others since these institutions are guaranteed. In addition to being a place for routine zakat and sedekah distribution, the distribution of zakat institutions in its distribution is more focused on the community around the place of residence. Hence, it will be more helpful and more targeted to the local community. However, some respondents did not channel their funds through BAZNAS and LAZ (56\%) due to the distribution range of BAZNAS and LAZ. It is considered to only cover certain groups. Another $27 \%$ of respondents argue that the method of fund collection carried out by BAZNAS and LAZ is inappropriate. Thus, they preferred to distribute funds directly or through other institutions. Meanwhile, 15\% suggest that BAZNAS and LAZ are inexperienced during the COVID-19 pandemic. Respondents considered them as a wrong institution in distributing funds to respond to the COVID-19 pandemic. 


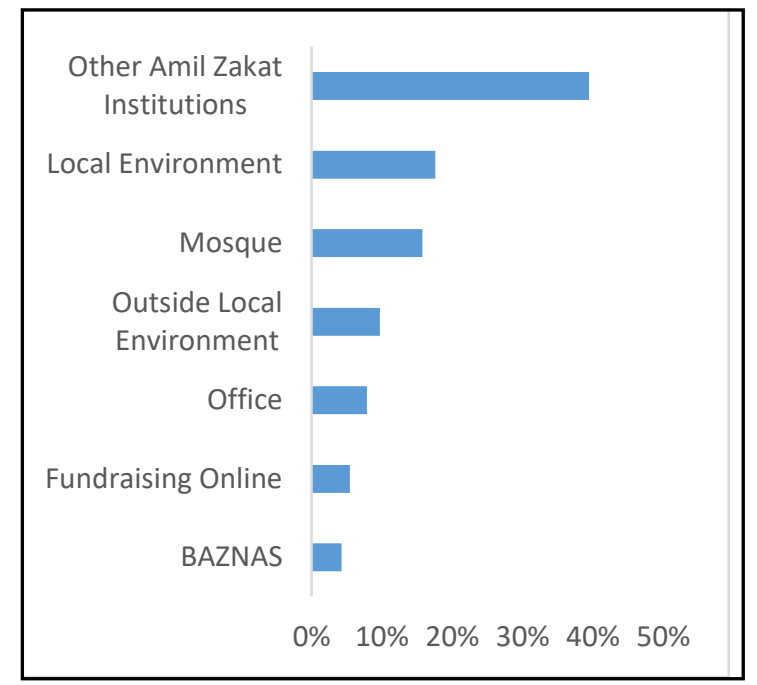

Figure 7. Fund Disbursement before COVID-19 Pandemic

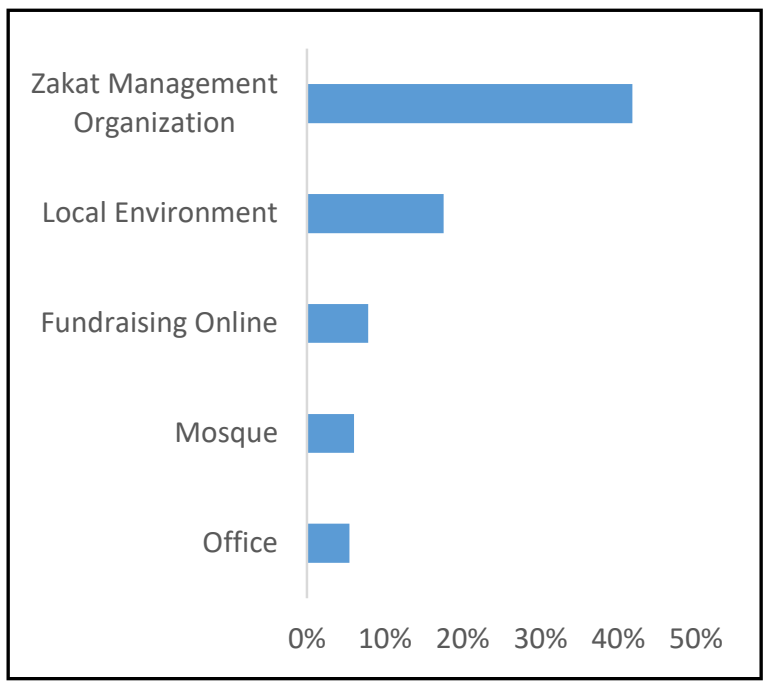

Figure 8. Fund Disbursement in the time of COVID-19 Pandemic

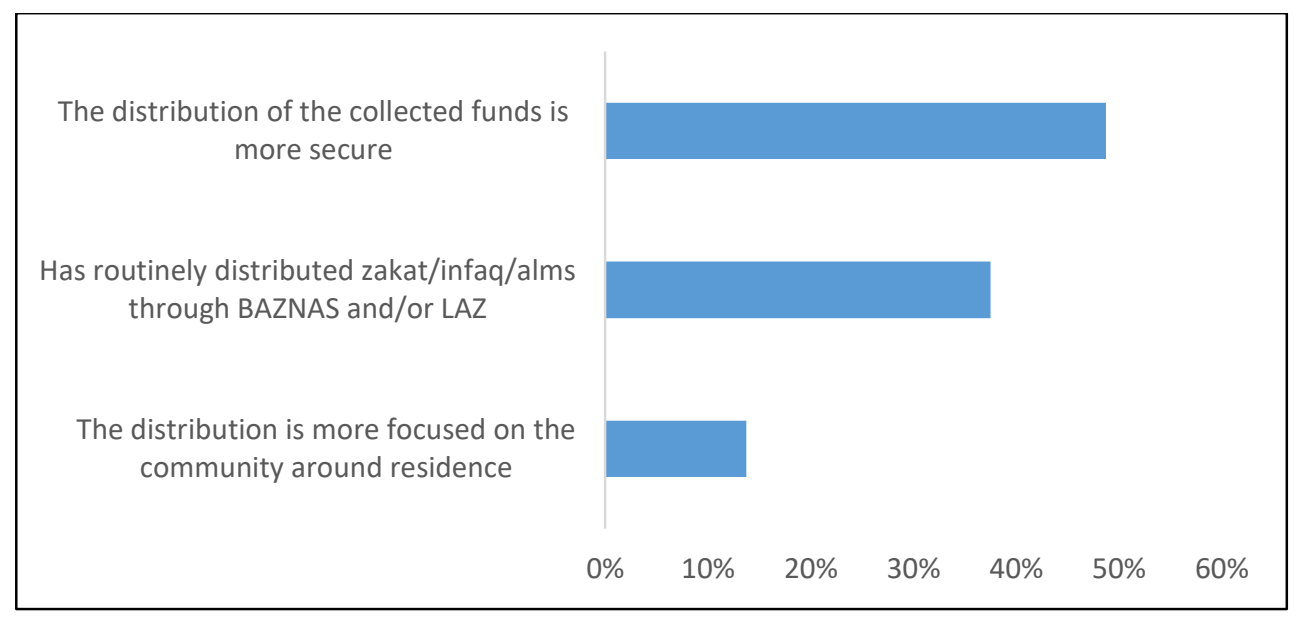

Figure 9. Respondents' Reasons for Disbursing Zakat funds in Zakat Institutions (BAZNAS/LAZ)

\section{Inferential Analysis}

This study employed inferential analysis using the Tobit regression to estimate the model. The Tobit model is designed to estimate a linear relationship between the response variables and the independent variables when there are either down/left or up/right sensors in the response variable. In this study, the researcher used the lower limit of 0 and the upper limit of 1 for the response variable. The model was used to estimate the probability of respondents to make donations for COVID-19 prevention.

Table 2 shows that the variables of education, length of stay, and expenses have a significant effect on the percentage of fund disbursement for COVID-19 with different levels of significance. The variable of education, length of stay, and expenses have a positive coefficient value that the higher the level of education, the length of stay, and 
the greater the expenses, the more the percentage of funds from income disbursed for COVID-19.

The coefficient column in Table 2 is the actual variable that the coefficient is the expected marginal effect for the expected value $[E(y \mid 0<y<1)]$. The interpretation of the marginal effect is done by looking at the sign of the coefficient and the value of the estimated coefficient as the impact of changes from the independent variable to the dependent variable that does not contain censored observations. The dependent variable (y) has the condition that the left/lower limit is not censored and the right/upper limit is 1 . If the coefficient of marginal effect is positive, the independent variable has an effect in the direction of the response variable. If the coefficient of marginal effect is negative, the independent variable has the opposite effect with the response variable.

Table 2. Tobit Regression Results

\begin{tabular}{lllc}
\hline Variable & Coefficient & t ratio & P value \\
\hline Gender & 0.003059 & 0.18 & 0.854 \\
Age & -0.001750 & 1.44 & 0.102 \\
Family Size Size & 0.000749 & 0.27 & 0.789 \\
Education & 0.077597 & 2.00 & $0.048^{* *}$ \\
Main Occupation & -0.007253 & 1.18 & 0.242 \\
Side Occupation & -0.000596 & 0.53 & 0.597 \\
Length of Stay & 0.001491 & 1.92 & $0.051^{*}$ \\
Expenses & 0.052841 & 4.08 & $0.000^{* * *}$ \\
Cons & -0.921182 & & \\
\hline Prob > Chi2 & 0.000 & & \\
\hline Log likelihood & 68.576149 & \\
\hline Log likelihood at zero & 54.887585 & & \\
\hline Notes: Significat at leve & & \\
\hline
\end{tabular}

Notes: ${ }^{*}$ Significant at level 10\%; ${ }^{* *}$ Significant at level 5\%; ${ }^{* * *}$ Significant at level 1\%

The marginal coefficient can be interpreted as the involvement of variables in influencing the response variable. Table 3 shows the involvement of the level of education of the respondent as shown in the dy/dx column is associated with an increase of 0.07 in the probability of the respondent channeling their funds for handling COVID-19. The same thing occurs to the variables of the length of stay and expenses. The involvement of the variable of the length of stay is associated with an increase of 0.001 in the respondent's probability of channeling their funds. While the variable of expenses is also associated with an increase of 0.05 in the respondent's probability of disbursing their funds to handle COVID-19. 
Table 3. Marginal Effect after Tobit Regression

\begin{tabular}{llll}
\hline Variable & $\mathbf{d y} / \mathbf{d x}$ & $\mathbf{P}$ value & $\mathbf{X}$ \\
\hline Gender & 0.003059 & 0.854 & 0.391 \\
Age & -0.001750 & 0.102 & 36.72 \\
Family Size Size & 0.000749 & 0.789 & 1.041 \\
Gender & 0.077597 & 0.048 & 2.891 \\
Main Occupation & -0.007253 & 0.242 & 2.266 \\
Side Occupation & -0.000596 & 0.597 & 23.816 \\
Length of Stay & 0.001491 & 0.051 & 12.475 \\
Expenses & 0.052841 & 0.000 & 15.193 \\
\hline
\end{tabular}

Note: $\left(^{*}\right) \mathrm{dy} / \mathrm{dx}$ is for discrete change of dummy variable from 0 to 1

\section{Discussion}

This study uncovered factors influencing prosocial attitudes, in this case, the community's contribution in handling COVID-19 effect. These factors are education (Rietveld et al., 2013), length of stay (Allen, 2018), and expenses (Clotfelter \& Steuerle, 1981; James \& Sharpe, 2007). These three variables can increase a person's probability of disbursing their zakat funds for the handling of the COVID-19 pandemic. It is often associated with the attitude of generosity.

In regards to the variable of the level of education, this study suggests that the higher the education, the more the probability percentage of donations will be given during the COVID-19 pandemic. Higher education can be used as a measure of a person's sensitivity to the surroundings. It is said that the individual's tendency to behave generously depends on natural and upbringing factors; one of the factors that can determine the proportional behavior is education (Rietveld et al., 2013). Someone with a high level of education is considered to be more understanding, thus will be able to understand the surroundings.

A positive relationship between the level of education and generosity or prosocial behavior has been found by several researchers (Jin et al., 2021; Kamas \& preston, 2021; Lockwood et al., 2021). This also applies to the percentage of the number of funds donated, in which the higher the education level, the higher the percentage of donations given from the income (Bekkers \& Wiepking, 2011). This is based on the reason that a strong generosity or altruism is due to one's high level of education (Aligargh et al., 2021; Ninglasari, 2021). Those with higher education are often asked to volunteer more often. In addition, they tend to be asked to do volunteer work and occupy positions that require leadership qualities. Thus, the level of education has a very important role.

The variable of the length of stay has a positive effect on the percentage of fund disbursement for the handling of the COVID-19 pandemic. Empathy, affection, and other emotions will be higher in groups of individuals who have long been formed. 
This means that a person with a longer stay will be more sensitive to social activities in the form of fund disbursement to the surrounding environment. However, other studies have shown that people who act prosocially or generously have expectations that their generosity will be reciprocated and they feel it will help their reputation in certain groups (Allen, 2018). Prosocial behavior is also influenced by cultural norms. Hence, it will be easier to be formed in individuals involved in certain groups.

Meanwhile, the amount of expenses that can represent wealth is also a factor that affects one's generosity. Based on some researches (Clotfelter \& Steuerle, 1981; James \& Sharpe, 2007), the poorest and richest people give most of their income to help each other or to charity. The exact relationship between income and charitable giving will vary by country. A study conducted in England and Wales found that people in the top quintile were the most likely to provide charitable giving (Li, 2015).

Social class shapes people's values, sensitivity, and compassion for others. During the COVID-19 pandemic, public generosity is considered to be increasing. Various humanitarian institutions, one of which is ACT (Aksi Cepat Tanggap) claim to have an increase in charity transactions. Those who give charity do not only come from certain community groups but also from various groups. In addition, based on the research conducted by Sen et al. (2020), the higher the income, the more the non-cash donations. The act of generosity is known as philanthropy.

The ability to measure generosity or philanthropy of giving of zakat to handle COVID-19 effect is important for researchers, policymakers, and practitioners. Researchers will need a measure of generosity towards the giving of zakat to develop and test the theory of charity behavior in this case empirically. A valid and reliable measure of attitudes that influence charitable behavior is important for policymakers who face difficult decisions involving the allocation of government resources to social issues. In addition, these measures assist practitioners to develop effective and efficient marketing strategies to attract and retain donors for zakat.

\section{Conclusion}

This study examines the role of Muslim zakat and sedekah funds as well as the factors affecting the amount of charity given by respondents to help the community during the COVID-19 pandemic. The analysis employed the Tobit regression. In general, this study found that $50 \%$ of the total respondents admitted to donating funds during the pandemic, and 50\% of them donated regularly. Most of the respondents who donated their funds were through Zakat Management Organizations (BAZNAS and LAZ) by $56 \%$. The remaining $44 \%$ donated directly to mustahik. This study also found that the variables that significantly affect the number of funds disbursed was education level, length of stay in the area, and monthly expenses. Observed from each variable 
coefficient, all three increase the probability of increasing the percentage of donations given during the COVID-19 pandemic.

The research results are expected to improve Islamic Social Finance in Indonesia. Many people donating to LAZ and BAZNAS during the pandemic indicate that strong public trust in OPZ. Thus, efforts to develop a more professional LAZ and BAZNAS are crucial to optimize public trust. In addition, the results of other studies related to the characteristics of philanthropist that increase their donations can be used as input in increasing fundraising. The results of the study also show that the higher the education, the greater the zakat given. This shows the important role of education in supporting the development of philanthropy in Muslim societies. To improve the quality of education, religious education for Muslims is essential to increase the awareness in distributing zakat and sedekah funds.

This study used data obtained from online surveys during the pandemic. It presents a considerable challenge in drawing general conclusions. However, the research results can be used as an insight into the development of future Islamic social finance. Future research can focus on improved sampling methods, especially if the pandemic has got better. In addition, future research can also be complemented by indepth interviews with muzaki, mustahik, and OPZ as complete sources of information for further analysis.

\section{Authors' Declaration}

The authors made substantial contributions to the conception and design of the study. The authors took responsibility for data analysis, interpretation and discussion of results. The authors read and approved the final manuscript.

\section{ORCID}

Agni Alam Awirya (D) https://orcid.org/0000-0003-3843-9062

Indah Piliyanti (D) https://orcid.org/0000-0001-9993-8899

Dian Novita (D) https://orcid.org/0000-0002-7741-3028

\section{References}

Abdullahi, I. A., \& Kumar, P. (2016). Gender differences in prosocial behaviour. The International Journal of Indian Psychology, 3(4), 171-175.

Aligarh, F., Nugroho, A., Raharja, B. S., Pratama, B. C., \& Wirayuda, A. W. (2020). Do Individual Factors, Religiosity Factors, and Demographic Factors Predict Intention to Pay Zakat?. Al-Uqud: Journal of Islamic Economics, 5(1), 151-165. https://doi.org/10.26740/al-uqud.v5n1

Allen, S. (2018). The Science of Generosity. A white paper prepared for the John 
Templeton Foundation by the Greater Good Science Center at UC Berkeley Al-Faizin, A. W., Insani, T. D., \& Widiastuti, T. (2017). Zakat as an Obligatory System and its Implications for Social Psychology of Society (Social Tafsīr of Sūrah AlTawbah: 103). International Journal of Zakat, 2(2), 43-53.

Andreoni, J., Nikiforakis, N., \& Stoop, J. (2021). Higher socioeconomic status does not predict decreased prosocial behavior in a field experiment. Nature communications, 12(1), 1-8. https://doi.org/10.1038/s41467-021-24519-5

Amalia, K. M. (2012). Potensi Dan Peranan Zakat Dalam Mengentaskan Kemiskinan Di Kota Medan. Jurnal Ekonomi Dan Keuangan, 1(1), 70-87.

Asmalia, S., Kasri, R. A., \& Ahsan, A. (2018). Exploring the Potential of Zakah for Supporting Realization of Sustainable Development Goals (SDGs) in Indonesia. International Journal of Zakat, 3(4), 51-69. https://doi.org/10.37706/IJAZ.V3I4.106

Bekkers, R. and Wiepking, P. (2011). A literature review of empirical studies of philanthropy: Eight mechanisms that drive charitable giving. Nonprofit and Voluntary Sector Quarterly, 40(5), 924 - 973

Clotfelter, C. T., \& Steuerle, C. E. (1981). Charitable con-tributions. In H. Aaron \& J. Pechman (Eds.), How taxes affect economic behavior (pp. 404-437). Washington, DC: Brookings Institution.

Fauzia, A. (2016). Filantropi Islam, Sejarah dan Konstelasi Masyarakat Sipil dan Negara di Indonesia. Yogyakarta: Gading Publishing.

Galea, S., \& Abdalla, S. M. (2020). COVID-19 Pandemic, Unemployment, and Civil Unrest: Underlying Deep Racial and Socioeconomic Divides. Journal of the American Medical Association, 324(3), 227-228.

https://doi.org/10.1001/jama.2020.11132

Haider Syed, M., Khan, S., Raza Rabbani, M., \& Thalassinos, Y. E. (2020). An artificial intelligence and NLP based Islamic FinTech model combining Zakat and QardhAl-Hasan for countering the adverse impact of COVID-19 on SMEs and individuals. International Journal of Economics and Business Administration, 8(2), 351-364.

Hassan, N. \& Noor, A. (2015). Do Capital Assistance Programs by Zakat Institutions Help the poor?. Procedia Economics and Finance 2015, proceedings of International of Accounting and Business Conference 2015, Jakarta: IABC 2015, 551-562.

Iskandar, A., Possumah, B. T., \& Aqbar, K. (2020). Peran Ekonomi dan Keuangan Sosial Islam Saat Pandemi COVID-19. Jurnal Sosial \& Budaya Syar-I, 7(7), 625638. https://doi.org/10.15408/sjsbs.v7i7.15544

Ismail, H., Rohmawati, A., Rakhmat, R., \& Hidayati, N. N. (2021). Lazisnu Dan Penanggulangan COVID 19; Impelemntasi Fatwa MUI Nomor 23 Tahun 2020 
Tentang Pemanfaatan Zakat Infak Shadaqah. At-Tahdzib: Jurnal Studi Islam dan Muamalah, 9(1), 19-25.

James, R. N., \& Sharpe, D. L. (2007). The Nature and Causes of the U-Shaped Charitable Giving Profile. Non-profit and Voluntary Sector Quarterly, 36(2), 218238. https://doi.org/10.1177/0899764006295993

Jin, S., Balliet, D., Romano, A., Spadaro, G., Van Lissa, C. J., \& Agostini, M. (2021). Intergenerational conflicts of interest and prosocial behavior during the COVID19 pandemic. Personality and Individual Differences, 171(2), 110535.

https://doi.org/10.1016/j.paid.2020.110535

Kamas, L., \& Preston, A. (2021). Empathy, gender, and prosocial behavior. Journal of Behavioral and Experimental Economics, 92, 101654.

https://doi.org/10.1016/j.socec.2020.101654

Keister, Lisa A, \& Stephanie M. (2000). Wealth Inequality in the United States. Annual Review of Sociology, 26, 63-81.

Li, Y. (2015). The flow of soul: a sociological study of generosity in England and Wales (20012011). In The Hand book of Research Methods and Applications on Social Capital (pp. 40-59). https://doi.org/10.4337/9780857935854

Lockwood, P. L., Abdurahman, A., Gabay, A. L., Drew, D., Tamm, M., Husain, M., \& Apps, M. A. (2021). Aging Increases Prosocial Motivation for Effort. Psychological Science, 32(5), 668-681. https://doi.org.10.1177/0956797620975781

Martin, A., Markhvida, M., Hallegatte, S., \& Walsh, B. (2020). Socio-economic impacts of COVID-19 on household consumption and poverty. Economics of disasters and climate change, 4(3), 453-479. https://doi.org/10.1007/s41885-020-00070-3

Masrul, I. S., \& Huda, N. (2021). Islamic Social Finance Optimalization For Economic Growth (Covid 19 in Indonesia). Laa Maisyir: Jurnal Ekonomi Islam, 8(1), 1-12. https://doi.org/10.24252/lamaisyir.v8i1.16517

Munandar, E., Amirullah, M., \& Nurochani, N. (2020). Pengaruh Penyaluran Dana Zakat, Infak Dan Sedekah (ZIS) dan Pertumbuhan Ekonomi Terhadap Tingkat Kemiskinan. Al-Mal: Jurnal Akuntansi Dan Keuangan Islam, 1(1), 25-38. https://doi.org/10.24042/AL-MAL.V1I1.5321

Mursal, M., Ritonga, M., Sartika, F., Lahmi, A., Nurdianto, T., \& Alam, L. (2021). The contribution of Amil Zakat, Infaq and Shadaqah Muhammadiyah (LAZISMU) institutions in handling the impact of COVID-19. Journal of Sustainable Finance $\mathcal{E}$ Investment, 1-7. https://doi.org/10.1080/20430795.2021.1886550

Nacoti, M., Ciocca, A., Giupponi, A., Brambillasca, P., Lussana, F., Pisano, M., \& Montaguti, C. (2020). At the epicenter of the COVID-19 pandemic and humanitarian crises in Italy: changing perspectives on preparation and 
mitigation. NEJM Catalyst innovations in care delivery, 1(2).

https://doi.org/10.1056/CAT.20.0080

Ninglasari, S. Y. (2021). Determinants of Online Zakat Intention amongst Muslim Millennials: An Integration of Technology Acceptance Model and Theory of Planned Behavior. Shirkah: Journal of Economics and Business, 6(2), 227-245. doi:https://doi.org/10.22515/shirkah.v6i2.387

Ozili, P. K. (2021). COVID-19 pandemic and economic crisis: the Nigerian experience and structural causes. Journal of Economic and Administrative Sciences, 37(4), 401418. https://doi.org/10.1108/JEAS-05-2020-0074

Piliyanti, I. (2020). Evaluasi Akuntabilitas Lembaga Amil Zakat di Indonesia:

Tinjauaun dari Pemanfaatan Teknologi Informasi dalam Perkembangan Praktik Zakat Kontemporer di Asia Tenggara. Kyoto Series of Islamic Economic Studies, 3, 61-80.

Poole, D. N., Escudero, D. J., Gostin, L. O., Leblang, D., \& Talbot, E. A. (2020). Responding to the COVID-19 pandemic in complex humanitarian crises. International journal for equity in health, 19(1), 1-2. https://doi.org/10.1186/s12939020-01162-y

Rietveld, C. A., Medland, S. E., Derringer, J., Yang, J., Esko, T., Martin, N. W., Koellinger, P. D. (2013). Individuals Identifies Genetic Variants Asso-ciated with Educational Attainment. Science, 340(6139), 1467-1471. https://doi.org/10.1126/science.1235488

Saladin, M., Rasool, A., Fauzi, M., Harun, M., Salleh, A. M., Aini, N., \& Idris, H. (2011). Poverty Measurement in Malaysian Zakat Institutions: A Theoretical Survey. Jurnal Ekonomi Malaysia, 45(1), 123-129.

Saputra, H. (2020). Zakat Sebagai Sarana Bantuan bagi Masyarakat Berdampak COVID-19. Al-Ijtima i: International Journal of Government and Social Science, 5(2), 161-175. https://doi.org/10.22373/JAI.V5I2.549

Saputro, E. G., \& Sidiq, S. (2020). The Role of Zakat, Infaq and Shadaqah (ZIS) in Reducing Poverty in Aceh Province. International Journal of Islamic Economics and Finance (IJIEF), 3(0), 63-94. https://doi.org/10.18196/IJIEF.3234

Sen, A., Chatterjee, R.S., Nayak, N.C. (2020). Determinants of Individual Giving Behavior in Urban India. Voluntas, 31, 271-285. https://doi.org/10.1007/s11266017-9913-6

Smith, D. H. (2016). Determinants of Voluntary Association Participation and Volunteering: A Literature Review. Nonprofit and Voluntary Sector Quarterly, 23(3), 243-263. https://doi.org/10.1177/089976409402300305

Sulaeman, S., Majid, R., \& Widiastuti, T. (2021). Zakat and Its Impact on SocioEconomic Welfare Before COVID-19 Pandemi in Indonesia. International Journal 
of Zakat, 6(2), 75-90. https://doi.org/10.37706/IJAZ.V6I2.301

Sumner, A., Hoy, C., \& Ortiz-Juarez, E. (2020). Estimates of the Impact of COVID-19 on Global Poverty. WIDER working paper (No. 2020/43).

https://doi.org/10.35188/UNU-WIDER/2020/800-9

Tobin, J. (1958). Estimation of relationships for limited dependent variables. Econometrica, 26(1), 24-36.

Umar, U.H., Baita, A.J., Haron, M.H.B. and Kabiru, S.H. (2021). The potential of Islamic social finance to alleviate poverty in the era of COVID-19: The moderating effect of ethical orientation. International Journal of Islamic and Middle Eastern Finance and Management. https://doi.org/10.1108/IMEFM-07-2020-0371

Van Reekum, R., Stuss, D. T., \& Ostrander, L. (2005). Apathy: Why care? Journal of Neuropsychiatry and Clinical Neurosciences, 17(1), 7-19. https://doi.org/10.1176/JNP.17.1.7

Wahyu, A. R. M., \& Anwar, W. A. (2020). Management of Zakat at BAZNAS Regency Sidrap during COVID-19's Pandemi. Jurnal Iqtisaduna, 1(1), 1-12.

Walpole, R. E. (1995). Pengantar Statistika edisi ke-3. Jakarta: Gramedia Pustaka Utama. Wooldridge, J. M. (2002). Econometric analysis of cross section and panel data. Cambridge, MA: MIT Press. 